\title{
Oilseed camelina (Camelina sativa L Crantz): production systems, prospects and challenges in the USA great plains
}

\begin{abstract}
Identifying crops that are adapted to semi-arid environments of the central and northern Great Plains (GP) has been a major challenge. An alternative crop with potential for semi-arid crop production in the GP is camelina (Camelina sativa L. Crantz). Compared to other oilseed crops, research has shown spring camelina to be cold and drought tolerant requires relatively low agricultural inputs and well adapted to semi-arid regions. Because of these agronomic attributes, camelina has been promoted as a low-input biofuel crop for the drier regions of the GP. Camelina seed has higher oil content $(>35 \%)$ with unique properties for industrial and nutritional applications. For example, a blend of camelina-based jet fuel tested in commercial and military flights in the US met all aviation fuel specifications and performance. The oil contains $40 \% \alpha$-linolenic acid (18:3n-6) an omega-3 fatty acid which has important implication in human and animal diets. Thus camelina has potential for commercial biofuel production and other industrial uses. However, there are limited production recommendations for camelina and the benefits and challenges of adopting camelina in cereal-based crop production systems in the GP have not been sufficiently explored. In addition, the lack of a reliable market outlet and low profitability when compared to other oilseeds are presently hampering camelina adoption by growers. Agronomic research to identify suitable camelina genotypes, seeding dates and soil fertility requirements are needed to develop site-specific production recommendations for camelina in the GP. Plant breeding efforts to develop desirable varieties with improved seed yield, oil content and fatty acids composition and tolerance to heat stress needs to be explored. Research efforts into perfecting alternative uses for camelina oil and meal such as using camelina as a drop-in product for adhesives, films, coatings, packing materials and plastics will expand the market beyond biodiesel. An expanded niche market will enhance the economic viability of camelina as a commercial oilseed in the GP.
\end{abstract}

Keywords: great plains, camelina, adhesive, films, coatings, packing materials, plastics
Volume 2 Issue 2 - 2015

\author{
Augustine K Obour,' Henry Y Sintim, ${ }^{2}$ Eric \\ Obeng, 'Valtcho D Jeliazkov (Zheljazkov) ${ }^{3}$ \\ 'Agricultural Research Center- Hays, Kansas State University, \\ USA \\ ${ }^{2}$ Department of Plant Sciences, University of Wyoming, USA \\ ${ }^{3}$ Columbia Basin Agricultural Research Center, Oregon State \\ University, USA
}

Correspondence: Augustine Obour K,Agricultural Research Center-Hays, Kansas State University, Agricultural Research Center- Hays, 1232 240th Avenue, Hays, KS Kansas 6760I, USA, Tel 785-625-3425, Email aobour@ksu.edu

Received: December 05, 2014 | Published: March 18, 2015
Abbreviations: GP, great plains; $\mathrm{CO}$, colorado; KS, kansas; MT, montana; ND, north dakota; NE, nebraska; NM, new Mexico; OK, Oklahoma; SD, South Dakota; TX, texas; WY, Wyoming; WF, wheat-fallow; CT, conventional tillage; SOM, soil organic matter; RT, reduced tillage; NT, no-till; N, nitrogen; S, sulfur; FDA, food and drug administration; FCIC, federal crop insurance corporation

\section{Introduction}

The Great Plains (GP) region in the United States span from the middle of the continental USA about the 100th meridian westward to the Rocky Mountains and from northern Texas to the Canadian border. ${ }^{1}$ The Great Plains covers several states in the central part of the US including Colorado (CO), Kansas (KS), Montana (MT), North Dakota (ND), Nebraska (NE), New Mexico (NM), Oklahoma (OK), South Dakota (SD), Texas (TX) and Wyoming (WY) (Figure 1) http:// www.unl.edu/plains/about/map.shtml The region produces more than $60 \%$ of the total wheat produced in the USA. ${ }^{2}$ The predominant wheat production system in this region is wheat-fallow (WF) or wheatsummer crop -fallow. In a WF cropping system wheat is usually planted in September and harvested in June of the following year, followed by a 14-month fallow period. The fallow phase allows soil moisture accumulation to recharge the soil profile and hence stabilizes crop production by reducing the chance of crop failure. Research evidence however, showed that the fallow phase in the cropping system is not efficient in moisture storage. Precipitation storage efficiency during fallow is $<30 \%$ of the total precipitation received during the fallow period. ${ }^{3}$ Besides, the use of conventional tillage (CT) operations for weed control during fallow has resulted in insufficient crop residue return to the soil, depletion of soil organic matter (SOM), declining soil fertility, soil erosion and inefficient water storage. ${ }^{4}$

In recent years, introduction and adoption of reduced tillage (RT) and no-till (NT) practices have led to increased moisture storage and allowed crop intensification in most regions of the GP. For example, precipitation storage efficiency in a NT, WF system was $35 \%$ compared to $20 \%$ in a CT, WF cropping system. ${ }^{5}$ Over $75 \%$ of precipitation received during the fallow phase of WF system is lost to evaporation, runoff, deep percolation and weeds. ${ }^{6}$ Replacing fallow with frequent cropping will increase the amount of residue returned to the soil, protect the soil against wind and water erosion and potentially increase nutrient cycling through SOM decomposition. Economically, 
intensive cropping combined with RT has been shown to be more profitable compared to WF systems in the GP. ${ }^{7,8}$

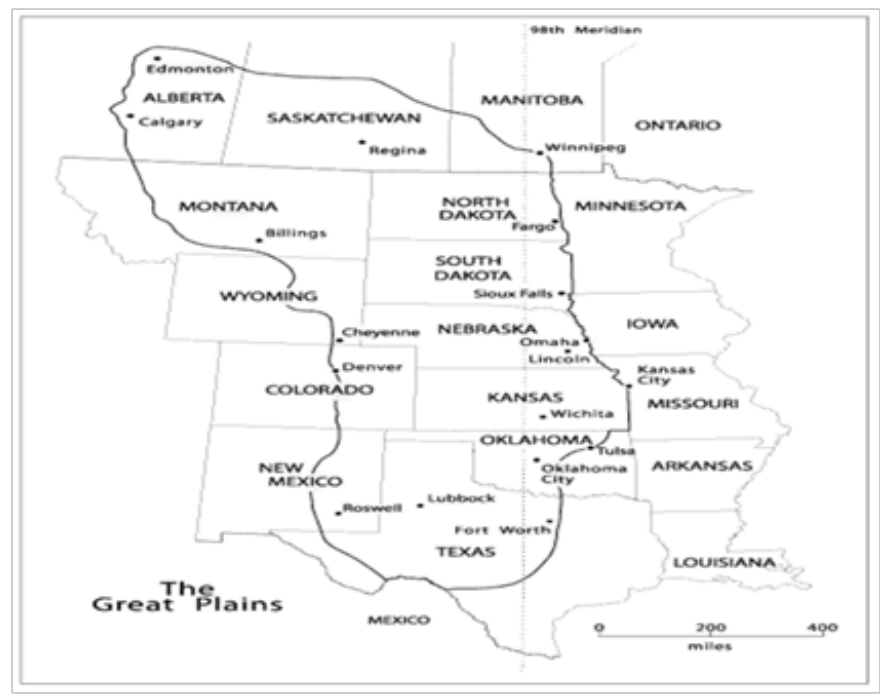

Figure I Map showing the US Great Plains. (http://www.unl.edu/plains/about/ map.shtml).

Saseendran et al., ${ }^{9}$ reported that the average precipitation received in the two-year period of WF rotation supplies more water than a single wheat crop can use suggesting the possibility of replacing fallow in WF rotation with a suitable crop that has unique agronomic and economic potential. The challenges to cropping systems intensification in the GP is to identify alternative crops that are adapted to the semi-arid climate and also fit into existing crop rotation systems in the region. Considerable attention has been given to oilseeds as potential alternative crop to replace the fallow period. Replacing the fallow phase in non-irrigated wheat production systems with a bioenergy oilseed crop will allow for a bioenergy raw material production without compromising exiting agricultural land use for food production and enhance economic and environmental sustainability of wheat production.

Oilseeds have been identified as one of the seven bioenergy crops by United States Department of Agriculture (USDA) and Department of Energy. The U.S. Renewable Fuels Standards (effective July 10, 2010) has a mandate that the American economy will be using 36 billion gallons of renewable transportation fuel per year by $2022 .{ }^{10} \mathrm{Of}$ the 36 billion gallons from biofuels, the USDA estimated that 0.5 billion gallons will come from oilseed crops. Therefore, biofuel from oilseed crops are expected to play a significant role in our efforts to mitigate global climate change caused by greenhouse gas emissions from fossil fuels. An oilseed crop mentioned in the USDA report that has potential for bio-diesel production in the GP is camelina. ${ }^{10}$ Biodiesel (fatty acid methyl esters after transesterification) prepared from camelina oil has fuel properties (low temperature operability, acid value, kinematic viscosity, lubricity, cetane number, etc.) similar to those of biodiesel produced with soybean oil. ${ }^{11}$ In addition, cold pressed filtered neat oil (straight vegetable oil) prepared from camelina seeds produced greater power output $(43.3 \mathrm{Kw})$ compared with $38.5 \mathrm{~kW}$ for mineral diesel fuel, but fuel consumption of the tested vehicle was greater with camelina neat oil than the mineral diesel fuel. ${ }^{12}$

Compared to other oilseed crops, research has shown camelina to be cold and drought tolerant ${ }^{13}$ requires relatively low agricultural inputs and well adapted to water-limited environments in the GP. ${ }^{14}$
Spring camelina is a short season crop, requiring about 85 to 100days from planting to maturity. ${ }^{15}$ The short growth cycle allows camelina to be planted in early spring and harvested in June. This allows enough time for soil water recharge for planting the subsequent wheat crop in the fall. Cropping systems studies in Conrad, MT and Lingle, WY has shown that camelina can replace fallow in WF systems with minimal yield reductions (about $6 \%$ ) in wetter years. ${ }^{16}$ But in drier years, a $13 \%$ and $30 \%$ reduction in wheat yields following camelina were reported in Conrad and Lingle respectively. ${ }^{16}$ Our ongoing studies at Wyarno, near Sheridan, WY showed $18.5 \%$ reduction in winter wheat yield following spring camelina in the 2013/2014 cropping season. ${ }^{17}$ The $18.5 \%$ reduction in wheat yield following camelina compared to those following the fallow phase was probably due to the prolonged fallow period (24-month fallow because the study was established on initial fallowed field) than what is usually practiced.

Despite its potential as an alternative bioenergy crop for semiarid cropping systems in the GP, limited research has been conducted on camelina and its agronomic potential and industrial applications remains largely underexploited. The purpose of this review is to a) provide information on agronomic potential for camelina production in semi-arid environments in the GP; b) explore current use and potential industrial applications for camelina; and c) outline challenges and prospects for future research to ensure economic viability of camelina production in the GP.

\section{Deciding on a crop for fallow replacement}

Crops adopted to replace the fallow phase in the predominant WF or wheat-summer crop-fallow system must add an agronomic benefit to the cropping system, relatively easy to manage with minimum pest and disease infestations, compatible with existing farm machinery and improve farm income. Incorporating oilseeds into cereal-based rotational systems has been suggested as a means to diversify and increase profitability of dry land crop production in the GP. ${ }^{18}$

\section{Potential oilseed crops}

Different scientists have evaluated several oilseeds across the GP for their potential in replacing fallow in dry land crop production in the region. Among the oilseed crops that have received considerable attention for semi-arid production includes camelina, canola (Brassica napus), Indian brown mustard (Brassica juncea), safflower (Carthamus tinctorius), sunflower (Helianthus annuus) and soybean (Glycine max).Though most of the crops can be grown in the GP, not all can be incorporated into semi-arid wheat-based crop rotations because of water use, cold tolerance, diseases and pest issues. For instance, sunflower has been grown with some success in western Kansas ${ }^{19}$ and eastern Colorado. ${ }^{20}$ However, it has deeper root system and tends to extract significant amounts of water from the soil profile. Sunflower roots can extend beyond $218 \mathrm{~cm}$ in the soil ${ }^{21}$ and effective water extraction up to $165 \mathrm{~cm}$ of the soil profile has been observed..$^{20}$ The significant water withdrawals means yields of crops following sunflower in rotation will be adversely affected. For example, winter wheat yields were significantly reduced when grown after sunflower at Akron, $\mathrm{CO}^{22}$ In order to sustain wheat production and reduce crop failure, growers adopting sunflowers under semi-arid conditions will need to incorporate a longer fallow period after sunflower to recharge the soil profile for the subsequent crop.

Canola, mustard and camelina are early maturing crops requiring shorter growing days from planting to maturity. Of the three, canola is cultivated widely in the GP and has received considerable attention 
in terms of agronomic research and plant breeding efforts aimed at varietal development and improved oil quality. ${ }^{23-25}$ The improvements in the fatty acid composition, particularly reduction in the erucic acid levels had made canola the third most important vegetable oil in the world. ${ }^{23}$ Current availability of herbicide-resistant canola cultivars makes its cultivation very attractive to growers. This has resulted in an increase in total acreage of canola production over the past 20 years. ${ }^{26}$ Despite the market availability for canola, cost of production is relatively higher compared to other oilseeds. Besides, canola and mustard have extensive root system capable of drawing water from deeper soil depths, between 114 to $165 \mathrm{~cm}$ has been reported. ${ }^{18,27}$ Canola and mustard roots grow faster and develop more extensively than the roots of camelina. ${ }^{27}$ Canola and mustard thus require adequate sub-soil moisture to sustain the crop during flowering and seed filling which is usually not available under dry land conditions in the semiarid GP. Chemical treatment for flea beetles which attack young canola seedlings ${ }^{28,29}$ is another drawback to canola production. To minimize the spread of pest and diseases, it has been suggested that canola be grown every three to four years when rotated with small grains. ${ }^{30}$ Pavlista et al., ${ }^{29}$ also reported seed damage in mustard and canola by birds which can cause significant yield loss.

Unlike canola, camelina is reported to be unaffected by flea beetle and bird damage, ${ }^{29}$ shows superior tolerance to cold, high drought tolerance and require less fertilizer to produce adequate yields, ${ }^{14}$ Camelina has shorter root systems and extracts water from shallow soil depths, thus fit well into dry land wheat production systems in the GP. However, camelina is susceptible to downy mildew that could potentially reduce yields. ${ }^{31,32}$

\section{Camelina: agronomy, prospects and challenges}

Camelina is indigenous to northern Europe. It is also known as 'gold-of-pleasure' or 'false flax' and belongs to the mustard family. Popularity of camelina waned after World War II when high yielding commodity grains and other oilseed crops+displaced it. It is a short season crop, requiring 85 to 100days from planting to maturity. ${ }^{15}$ It has shallow root system (Figure 2) and does not draw excessive moisture from the soil. ${ }^{14,34}$ Besides, camelina has unique fatty acid profile that makes it a good candidate for both nutritional and industrial applications. ${ }^{35}$ Camelina can either be grown as a spring or winter crop. However, most of the cultivation in the US is done in the spring. Spring seeding normally occurs in late March through the end of April and harvested in July. Winter cultivars are planted in the fall ${ }^{36}$ (September through October), they germinate and endue the cold temperatures by going into rosette stage and resumes growth when conditions are favorable in the spring. Growing camelina as a winter annual crop has distinct advantages. Fall-seeded camelina will emerge earlier in the spring and improve plant stand. Good stand establishment can suppress weeds, ${ }^{36}$ an added advantage because currently, there are no labeled herbicides for broadleaf weed control in camelina. Besides, fall planting will allow camelina to mature before the onset of hot summer temperatures that can affect seed yield. Fallseeded camelina may be harvested early, allowing for soil moisture storage and the production of a second crop. ${ }^{36,37}$ This will fit well into the traditional non-irrigated winter wheat-based cropping systems where moisture availability is critical to prevent crop failure.

Camelina plants become woody as the plant matures and can grow to heights ranging from 30 to $80 \mathrm{~cm} .{ }^{27}$ Camelina leaves are arrowshaped, pointed with smooth edges and are 5 to $9 \mathrm{~cm}$ long. ${ }^{35}$ The pods are teardrop-shaped with small seeds (Figure 3 ). Depending on variety and growing conditions, it can produce approximately 350,000 seeds per pound. ${ }^{35}$ On a dry weight basis, oil content of camelina ranges from 30 to $40 \%,{ }^{27,29}$ though values as high as $48 \%$ has been reported. ${ }^{38}$ Camelina is drought-tolerant crop that can thrive and produce reasonable yields in low moisture conditions. ${ }^{14}$ It has better spring freezing tolerance and drought tolerance compared to canola. ${ }^{15}$ Cold temperature in the spring is a major limited factor that affects oilseed crops when grown in the GP. In a controlled environment study, camelina seeds were shown to emerge at $0 \mathrm{C} .{ }^{39}$ Camelina seedlings can survive freezing temperatures of $-2^{\circ} \mathrm{C}$ that can cause significant injury in flax, mustard and rapeseed..$^{34}$

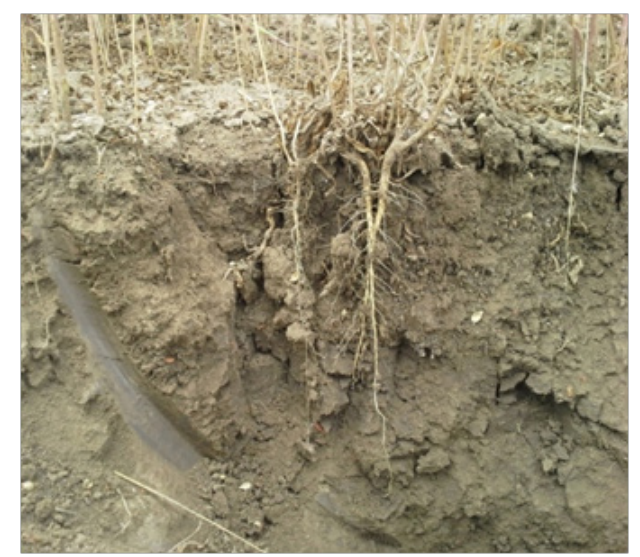

Figure 2 Soil profile distribution of camelina roots at an experimental site in Wyarno, near Sheridan, WY.

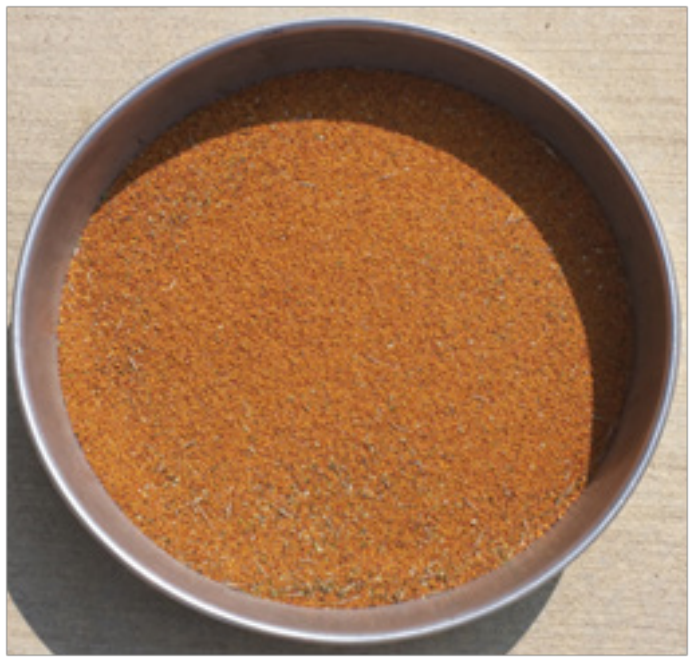

Figure 3 Threshed camelina seeds.

Seeding date is an important management practice that can be adapted to optimize camelina production. Early seeding allows camelina to flower before the usual summer heat and drought period that would help prevent pod abortion and increase seed yield. Planting beyond mid-April results in a significant decrease in seed yield (Table $1)$. Due to the small seed size (Figure 3), camelina is planted at shallow depths $(6-8 \mathrm{~mm})$ to ensure plant emergence and good stand establishment. Soil preparation, seeding rate, method of planting and seeding depth are all factors that have been found to affect plant establishment and subsequent seed yields. ${ }^{40-42}$ Seeding date may also depend on the environment and soil moisture availability. In a recent 
study in western Nebraska under irrigated conditions, camelina yields were not affected by seeding dates: 24 February, 24 March, 7 April, 21 April and 5 May in 2005 and 3 March, 3 April, 10 April, 27 April, 11 May and 2 June in $2006 .{ }^{29}$ The authors concluded that spring camelina seeded in April could provide good oil yields for Western Nebraska. Different seeding dates may be expected to affect fatty acid composition of oilseeds; however, a recent report found that camelina lipid profile is not influenced by temperature during the plant growth. ${ }^{43}$

In general, seeding rate of $5-7 \mathrm{~kg}$ seeds $\mathrm{ha}^{-1}$ is adequate to ensure good dense stand. Camelina can be grown under conventional tillage or no-till conditions. ${ }^{44}$ However, excessive crop residue can reduce seedling emergence with no-till, therefore seeding rates need to be increased under no-till. ${ }^{44}$ Also because of lack of registered herbicides for post-emergence weed control in camelina, pre-emergence weed control using glyphosate or a mixture of glyphosate and pendimethalin should be applied before planting. Currently, the only labeled herbicide for weed control in camelina is sethoxydim that control only grass weeds and has no effect on broadleaves. A recent study in MT on pre-emergence herbicides for weed control in camelina reported that quinclorac is safe to be used in camelina. ${ }^{45}$ The authors also reported that other chemicals such as dimethenamid-P, S-metolachlor and pendimethalin might have an acceptable level of crop safety when lower rates are used and therefore, could be registered for weed control in camelina. ${ }^{45}$ Residual herbicides from sulfonyl urea class compounds labeled for weed control in wheat and other cereal crops are reported to affect camelina emergence and stand establishment. ${ }^{44}$

Nutrient management is important in camelina production as it affects growth, yield and seed quality. Depending on pre-plant soil fertility, soil type and available soil moisture, $50-120 \mathrm{~kg} \mathrm{ha}^{-1}$ nitrogen $(\mathrm{N})$ and $10-25 \mathrm{~kg} \mathrm{ha}^{-1}$ sulfur $(\mathrm{S})$ are usually required for camelina production. ${ }^{13,46,47}$ Camelina's response to $\mathrm{N}$ and $\mathrm{S}$ are highly dependent on soil moisture availability and SOM. Our ongoing research efforts under non-irrigated conditions in KS and WY have shown that $\mathrm{S}$ fertilization had no significant effect on camelina seed yield. However, $\mathrm{N}$ application increased camelina seed yield with maximum yield occurring at 45 to $56 \mathrm{~kg} \mathrm{~N} \mathrm{ha}^{-1}$. In a previous study in WY, camelina showed no response to phosphorus $(\mathrm{P})$ even when the soil test $\mathrm{P}$ concentrations were very low. ${ }^{48}$ In responsive environments, applying $\mathrm{P}$ at 15 to $30 \mathrm{~kg} \mathrm{ha}^{-1}$ may be adequate.

Usually, minimal management practices are required after seeding to crop maturity. Harvesting should be done early when the plants reach physiological maturity. This is usually when $50-75 \%$ of the silicles are brown in color. ${ }^{41}$ Delaying harvest could cause seed yield loss due to pod shattering. In the event of uneven maturity, swathing the crop should be considered. Camelina can be harvested using regular grain combine with few adjustments. For direct combining, the height of the header must be set as high as possible, to avoid plugging the combine. Appropriate adjustment to airflow (usually low) of the harvester should be done to reduce seeds been blown away. Because low airflow of the harvester is used during harvest, sometimes camelina seeds may come out with a lot of plant material and seed cleaning may be needed. Installing a $0.35 \mathrm{~cm}$ screen over the lower sieves in the harvester will provide good separation of the seeds from stem pieces and pods. ${ }^{44}$ In MT, seed yields of 1680 to $2016 \mathrm{~kg} \mathrm{ha}^{-1}$ have been reported for camelina grown under non-irrigated conditions in areas receiving 400 to $500 \mathrm{~mm}$ of rainfall and 500 to $1344 \mathrm{~kg} \mathrm{ha}^{-1}$ in regions with lower precipitation..$^{15}$ Average yields of 450 and $1300 \mathrm{~kg} \mathrm{ha}^{-1}$ has been observed in our trials conducted in western KS and northwestern WY, respectively over 2013 and 2014 growing. A greater seed yield of $2880 \mathrm{~kg} \mathrm{ha}^{-1}$ has been reported in Eastern Europe. ${ }^{38}$

Table I Clinical and biochemical variables of individuals with overweight-obesity

\begin{tabular}{llll}
\hline \multirow{2}{*}{ Camelina Variety } & Date of Planting & & 16-Apr-13 \\
\cline { 2 - 4 } & S-Apr-13 & & 30-Apr-13 \\
\hline Blaine creek & Seed Yield $\left(\mathbf{~ k g ~ h a}^{-1}\right)$ & 246 & 274 \\
Pronghorn & 502 & 298 & 227 \\
Shoshone & 427 & 259 & 228 \\
Standard error & 228 & 50 & 50 \\
\hline
\end{tabular}

SD, standard deviation; BMI, body mass index;WC, waist circumference; $A C$, abdominal circumference; $H C$, hip circumference; RER, respiratory exchange ratio; $H R$, hear rate.

Due to its lower water requirements, camelina has greater potential for non-irrigated crop production systems in the GP. There have been few cropping systems efforts aimed at incorporating camelina into dry land wheat-based crop production. Early dry land research trials on spring camelina in the US northern GP indicated camelina produced greater or similar yields as other oilseed crops and had the least lodging and insect damage among the oilseeds tested. ${ }^{31}$ Similarly, Johnson et al., ${ }^{49}$ reported significantly greater camelina seeds yield than canola when the two crops were grown under non-irrigated conditions at Akron, CO. Replacing fallow with a biofuel crop as camelina has the potential to diversify cereal-based crop production systems in the GP. Crop diversification by adopting bioenergy crops will diversify markets, manage crop pests and increase overall crop productivity.
This has the potential to improve farm income, profitability and longterm sustainability of crop production systems in the region. Recent cropping systems studies in MT and WY have shown that camelina can replace fallow in wheat-fallow systems with minimal yield reductions in wetter years. ${ }^{15}$ Growing camelina on underutilized fallow strips in wheat-based production systems avoid direct competition for land use with food crops.

Despite its potential as an alternative bioenergy crop for dry land cropping systems in the GP, several constraints affect production and economic viability of camelina in the GP. Information on adapted winter and spring camelina genotypes, production systems and best agronomic production practices are limited. In addition, 
current production costs and lack of markets limit profitability of camelina. Harvesting and postharvest losses is another challenge in camelina production. Uneven maturation resulting in harvesting problems and subsequent yield loss due to shattering has also been reported. ${ }^{42,50}$ Another drawback to camelina production is downy mildew infestation. As mentioned previously, downy mildew has been found in camelina fields in MT, NE and the Pacific Northwest ${ }^{31,32}$ and there are no current recommendations to control downy mildew in camelina. The above constrains raises the need for more research to be conducted on camelina in order to optimize its production.

\section{Potential uses and industrial applications for camelina}

Camelina seed has high oil content with unique properties for both industrial and nutritional application. Based on reported seed yield, Moser $^{51}$ estimated camelina oil yield to be 106 to $907 \mathrm{~L} \mathrm{ha}^{-1}$, which is significantly greater than soybean $\left(247-562 \mathrm{~L} \mathrm{ha}^{-1}\right)$ and sunflower $\left(500-750 \mathrm{~L} \mathrm{ha}^{-1}\right)$. The oil contains about $60 \%$ polyunsaturated fatty acids mainly linolenic (18:2n-6) about $15 \%$ and $40 \% \alpha$-linolenic acid (18:3n-6), 30\% mono-unsaturated and $6 \%$ saturated fatty acids. ${ }^{15,52}$ Camelina oil is very high in $\alpha$-linolenic acid, an omega- 3 fatty acid that is essential in human and animal nutrition..$^{52}$ Because of the higher omega-3 fatty acid content, camelina oil has been promoted as a dietary supplement in human and animal nutrition. However, the presence of high erucic $\operatorname{acid}^{52,27}$ (2.3 to $\left.4.5 \%\right)$ makes higher dietary consumptions of camelina oil unsafe. The oil also contains high levels of $\gamma$-tocopherol (vitamin E) which confers a reasonable shelf life without the need for special storage conditions. ${ }^{52}$

Camelina as a feedstock for biofuel: Camelina seeds can potentially be used for biodiesel (fatty acid methyl esters) production. This is useful because of the insecurity related to fossil fuels. As a result, there has been increased demand for biofuel production. In order to sustain food production, oilseed crops used for biofuel production should be from non-human food sources. This makes camelina seeds, which have high oil content ( $>30 \%$ on dry weight basis) and is currently non-edible in-terms of human consumption, an attractive crop for biofuels. In addition, it has been demonstrated that camelina has negligible potential as an invasive weed if grown in a large scale as biodiesel crop. ${ }^{53}$

Studies have shown that camelina oil is a good feed stock for biodiesel (prepared via transesterification) production $^{54,55}$ and as a renewable jet fuel through hydrodeoxygenation/hydro cracking. ${ }^{51}$ In the US, several companies including Accelergy Corp., Altair, Inc., Biojet Corp. and sustainable Oils, LLC have successfully produced camelina-derived jet fuel. ${ }^{51}$ Recently, a blend of camelina-based jet fuel produced by Sustainable Oils in Montana was tested in commercial, military and private aviation flights in the U.S http://www.susoils. com/flights.php This camelina-based fuel met all aviation fuel specifications and performed well in both types of planes. Life cycle analysis showed that camelina-based jet fuel and biodiesels reduce carbon emissions by 75 and $80 \%$, respectively, compared to petroleum products. ${ }^{56}$ A recent study by Soriano et al. ${ }^{55}$ demonstrated that the fuel properties of camelina biodiesel (such as kinematic viscosity $\left(40^{\circ} \mathrm{C}\right)$, flash point, cloud point, cold filter plugging point and oil stability index) are similar to sunflower biodiesel properties. However, due to the high amounts of n-3-fatty acids in camelina oil, biodiesel prepared from camelina oil exhibited poor oxidative stability and showed the highest potential to form coke during combustion. While camelina biodiesel may have some undesirable fuel properties, it is comparable to soybean at the B20 level. ${ }^{55}$ Despite the fuel attributes, the current downward trend in oil prices makes biofuel production from alternative sources such as camelina unprofitable.

Camelina as a feed meal for animal nutrition: The by-product of camelina seeds after oil extraction can be used as feed meal for livestock. The meal is very nutritive with high levels of omega-3 fatty acids $(>35 \%)$, vitamin $\mathrm{E}$, crude protein $(>45 \%)$ and fiber $(10-11){ }^{57,58}$ Camelina meal has been used successfully as a protein and lipid antioxidant for pork meat patties. ${ }^{59}$ Cake derived from camelina meal has shown to increase unsaturated fatty acids in ewe's milk. ${ }^{60}$

Feed meal from camelina contains moderate to high amounts of erucic acid, ${ }^{27,52}(2.4-5 \%)$, sinapine $\left(2-4 \mathrm{mg} \mathrm{kg}^{-1}\right)$ and glucocinolates $\left(19-25 \mathrm{mmol} \mathrm{kg}^{-1}\right)$ which are anti-nutritive compounds. ${ }^{58,61,62}$ Morris $^{63}$ observed that high erucic acid in feed meal resulted in fat deposits in heart muscle and myocardial lesions in experimental animals. Likewise, glucoinolates in the feed meal caused impairment of growth and fertility, as well as irritation of gastro-intestinal mucosa, followed by local necrosis in livestock. ${ }^{62}$ Due to the health concerns associated with consuming camelina feed meal, the U. S. Food and Drug Administration (FDA) allows a maximum of $10 \%$ camelina feed meal to be included in rations for ruminants. ${ }^{64}$

Camelina for bio-based products: Camelina oil has potential for bio-based industrial application. The high amounts of unsaturated fatty acids (about 90\%) make camelina oil fast-drying which can be used for making polymers, varnishes, paints, cosmetics and dermatological products. ${ }^{65,66}$ Besides, vegetable oils with high unsaturated fatty acids can be epoxidized and used in many industrial applications such as lubricants, resins, coatings and adhesives. Kim et al., ${ }^{67}$ were able to optimize the epoxidation process for camelina oil using formic acid and hydrogen peroxide. The authors showed that epoxidized camelina oil has potential in the biopolymer industry for making pressure-sensitive adhesives, resins and coatings. Cosmetic products such as camelina lotion (Figure 4) and soaps (Figure 5) are marketed in smaller quantities in the USA by small businesses (e.g. Manor Hall Soap Company, Springfield, MA; TaDa Soap, Sheridan, WY; Siberian Tiger Naturals Inc., Seattle, WA). Camelina meal was shown to suppress Phymatotrichopsis omnivore (Duggar) sclerotial germination and hyphal growth at 5\% and 1\% application to soil, although camelina meal was less effective than the mustard meal. ${ }^{68}$ The fungus $\mathrm{P}$ omnivore causes cotton root rot, affecting cotton and alfalfa production in Texas. ${ }^{68}$ Alternative uses and markets for camelina such us bio-products and animal feeds are still in the developmental stages. Concerted research efforts is needed in this area to expand the market base for camelina to insure large scaled camelina production since grower adoption of the crop will depend on market availability.

Camelina current production and potential future markets: The state of Montana is the leading producer of camelina in the U. S.; however, production has been declining since 2009 (Table 2). The decline of camelina production in MT was because of the low market price for camelina seeds. Average sale price for camelina seed was $\$ 0.082 \mathrm{~kg}^{-1}$ in $2007 .{ }^{69}$ Craig Parker, Chief Executive officer of Willamette Biomass Processors, Inc., Rickreall, OR., indicated that his company's market price for camelina seeds was $\$ 0.073 \mathrm{~kg}^{-1}$ in 2014 (Personal communication). Compared to 2007, this represents $11 \%$ reduction in the sale price for camelina seeds. In order to encourage camelina production, the USDA- Federal Crop Insurance Corporation (FCIC) approved an insurance policy for camelina growers in 2013 
(FCIC-20170L) which was effective for 2014 and succeeding crop years. ${ }^{70}$ The policy allows up to $65 \%$ insurance coverage for camelina production. Although this incentive for producers could enhance

Table 2 Production trend of camelina in Montana State from 2007 to 2012 grower adoption, availability of market outlets will be the ultimate determinant for grower adoption.

\begin{tabular}{lllll}
\hline Year & Area (ha) & Production & \\
\cline { 2 - 5 } & Planted & Harvested & Seed yield $\left(\mathbf{k g ~ h a}^{-1}\right)$ & Total Seeds $(\mathbf{k g} \mathbf{x} \mathbf{1 0 0 0})$ \\
2007 & 9105 & 8256 & 670 & 5532 \\
2008 & 4937 & 3683 & 638 & 2350 \\
2009 & 8417 & 7891 & 689 & 5442 \\
2011 & 4006 & 3804 & 1132 & 4293 \\
2012 & 1012 & 971 & 841 & 816 \\
\hline
\end{tabular}

Source: USDA-NASS, 2013.

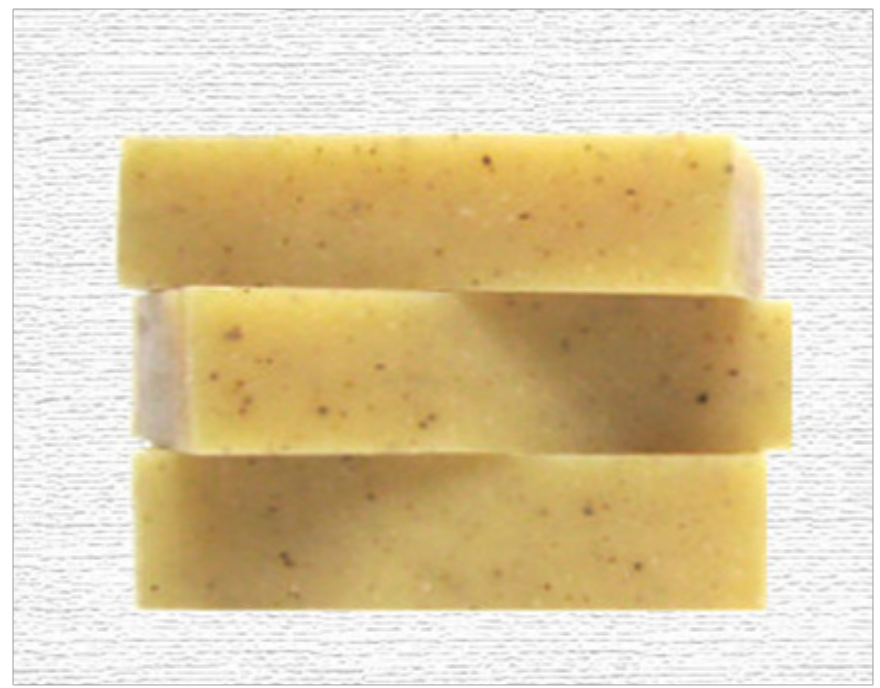

Figure 4 Camelina aloe natural complexion bar soap, a product of manor hall soap company.

Source: Manor hall soap company

http://www.manorhallsoapcompany.com/index.php?main_page=product info\&products_id=309.

Economic analysis conducted by Foulke et al., ${ }^{71}$ showed that the net profit of an on-farm biofuel (straight vegetable oil after pressing camelina seeds and filtering) production from camelina was relatively low. Their data indicated a breakeven price of $\$ 0.89 \mathrm{~L}^{-1}$ for an onfarm biodiesel produced (via pressing and filtering) from camelina grown in a dry land WF. Similarly, using a stochastic crop rotation budget and profitability sensitivity analysis, Keske et al., ${ }^{72}$ showed that there is a $51 \%$ probability that production of camelina for biofuel would be profitable when diesel price reaches $\$ 1.15 \mathrm{~L}^{-1}$. However, an experienced farmer who could produce camelina on a large scale has $90 \%$ probability of success when diesel price is at $\$ 0.83 \mathrm{~L}^{-1}$. The authors mentioned that a risk-averse farmer would not mind producing camelina when diesel price reaches $\$ 1.31 \mathrm{~L}^{-1}$ because at that diesel price, it would be more profitable to produce camelina for biodiesel. Notwithstanding, at the current downward trend in diesel and gasoline prices, production of biofuel (either on-farm production of neat oil for direct use or off-farm production of biodiesel through transesterification) from camelina is unprofitable.

A game changer that could improve profitability of growing camelina would be to find a niche market for camelina meal and oil. According to Reddy et al., ${ }^{73}$ using oilseed derived oils to produced synthetic polymers is far more profitable $\left(\$ 1750-2000\right.$ ton $\left.^{-1}\right)$ than when used as feed meal $\left(\$ 150-250 \operatorname{ton}^{-1}\right)$. However, this is usually not encouraged for edible oilseeds. Since camelina oil is non-edible, there is potential to expand that market. More importantly, ability to make use of camelina by-products for bio-products after oil extraction would be a major breakthrough. About $60-70 \%$ meal is available after camelina oil extraction, thus enough by-products would be available to support a bio-based product. Reddy et al., ${ }^{73}$ indicated that the use of the by-products of oilseeds for bio-product is a challenge due to their non-thermoplastic nature. Nonetheless, camelina by-products could be optimized to increase the tensile properties and potentially be used for films, fibers and thermoplastics when grafted with various acrylates. ${ }^{73}$

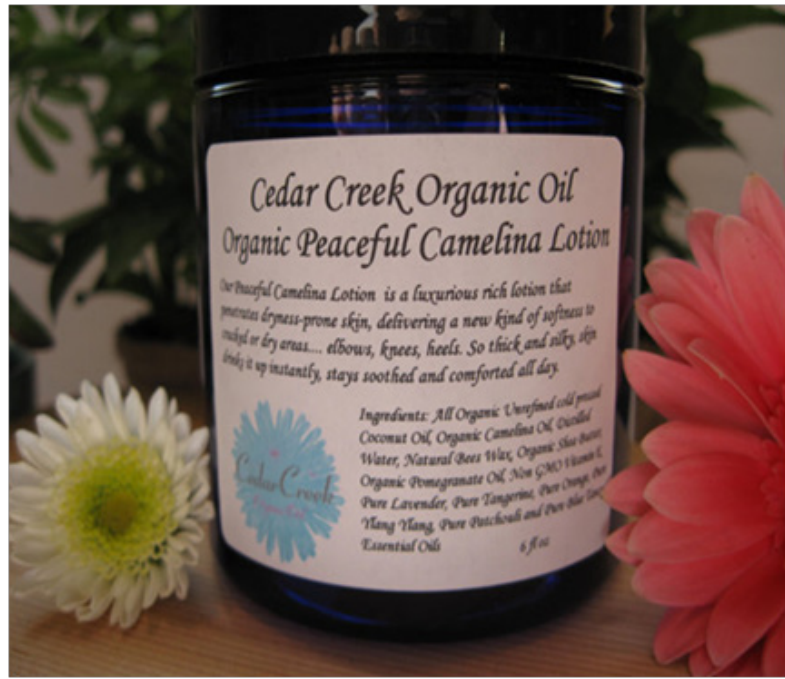

Figure 5 Organic citrus and camelina lotion, a product of cedar creek organic oil.

Source: Etsy Incorporation.

https://www.etsy.com/listing/I50082080/organic-citrus-camelina-lotion-I500. 


\section{Prospects for future research}

\section{Agronomic research}

Information on adapted winter and spring camelina genotypes, production systems and best agronomic production practices are limited. Research is needed to develop production recommendations for camelina as fallow replacement crop in non-irrigated cropping systems by conducting multi-location trials to evaluate planting dates and agronomic performance of spring and winter camelina genotypes across the GP, similar to what have been done in spring canola by Pavlista et al., ${ }^{29}$ Studies on $\mathrm{N}$ and $\mathrm{S}$ fertility requirements and incorporating camelina into cropping systems should be conducted. In additions, studies that will investigate post emergence broadleaf weed control are also required. Camelina yield loss because of seed shattering, harvesting and in postharvest management should be addressed. Studies to develop management strategies for downy mildew control should also be considered.

\section{Plant breeding efforts}

Unlike other oilseeds, limited plant breeding research has been conducted on camelina. Camelina cultivars in US are mostly of European origin, with limited improvement, that have been screened and adapted to regional environments. Plant breeding efforts are required to develop adaptable high-yielding camelina cultivars with improved seed yields, oil content and quality. Also developing cultivars less sensitive to heat stress will expand camelina growing environments to southern portions of the GP.

\section{Alternative uses}

Finding alternative uses for camelina meal and oil will expand the markets for camelina grown in the US. Research efforts with Universities and industry partners into perfecting alternative uses for camelina oil and meal by converting into bio-based products such as using camelina as drop-in products for adhesives, coatings and packaging materials will create ready markets for camelina growers.

\section{Conclusion}

Camelina holds promise as an oilseed crop with the potential for commercial biofuel production, animal feed and other industrial applications. The lack of a market and low profitability when compared to other oilseeds are presently hampering its adoption. Research on camelina is limited and its production systems are not been fully optimized. Agronomic research to identify suitable winter and spring camelina genotypes, seeding dates and soil fertility requirements are needed to develop site-specific production recommendations for camelina in the GP. Post-emergence broadleaf weed control, seed shattering, harvesting and post-harvest management strategies remain problematic. Plant breeding efforts aimed at developing desirable traits such as improved seed yield, oil content and fatty acids composition and tolerance to heat stress will expand camelina growing environments. Research efforts into perfecting alternative uses of camelina oil and meal in the bio-based products industry such as using camelina as a drop-in product for adhesive, films, coatings, packing materials and plastics will expand the market beyond biodiesel. An expanded market will enhance the economic viability of camelina as a commercial oilseed. The latter will ensure grower adoption of camelina in the Great Plains because of its desirable agronomic characteristics as a dry land crop.

\section{Acknowledgements}

The authors will like to thank the USDA-NIFA Biomass Research Development Initiative program for funding support. This is contribution number 15-208-J from the Kansas Agricultural Experiment Station.

\section{Conflict of interest}

The author declares no conflict of interest.

\section{References}

1. Unger PW, Baumhardt RL. Historical development of conservation tillage in southern Great Plains. In: Stiegler JH editor. Proceedings of the 24th Annual Southern Conservation Tillage Conference for Sustainable Agriculture, Oklahoma City, USA; 2001.

2. Paulsen GM, Shroyer JP. The early history of wheat improvement in the Great Plains. Agron J. 2008;100(Suppl 3):S70-S78.

3. Farahani HJ, Peterson GA, Westfall DG, et al. Soil water storage in dryland cropping systems:the significance of cropping intensification. Soil Sci Soc Am J. 1998;62(4):984-991.

4. Bowman RA, Vigil MF, Nielsen DC, et al. Soil organic matter changes in intensively cropped dryland Systems. Soil Sci Soc Am J. 1999;63(1):186191.

5. Nielsen DC, Vigil MF. Precipitation storage efficiency during fallow in wheat-fallow systems. Agron J. 2010;102(2):537-543.

6. Dalrylmple AW, Miller SD, Fornstrom KJ. Soil water conservation and winter wheat yield in three fallow systems. J Soil Water Cons. 1993;48(1):53-57.

7. DeVuyst EA, Halvorson AD. Economics of annual cropping versus cropfallow in the Northern Great Plains as influenced by tillage and nitrogen. Agron J. 2004;96(1):148-153.

8. Dhuyvetter KC, Thompson CR, Norwood CA, et al. Economics of dryland cropping systems in the Great Plains:a review. J Prod Agric. 1996;9(2):216-222.

9. Saseendran SA, Nielsen DC, Ahuja LR, et al. Simulated yield and profitability of five potential crops for intensifying the dryland wheatfallow production system. Agric Water Manag. 2013;116:175-192.

10. USDA Biofuels Strategic Production Report. A USDA Regional Roadmap to Meeting the Biofuels Goals of the Renewable Fuels Standard by 2022. USA: USDA Biofuels Strategic Production Report; 2010.

11. Moser BR, Vaughn SF. Evaluation of alkyl esters from Camelina sativa oil as biodiesel and as blend components in ultra-low-sulfur diesel fuel. Bioresour Technol. 2010;101(2):646-653.

12. Bernardo A, Howard-Hildige R, O’Connell A, et al. Camelina oil as a fuel for diesel transport engines. Ind Crops Prod. 2003;17(3):191-197.

13. Budin JT, Breene WM, Putnam DH. Some compositional properties of camelina (camelina sativa L. Crantz) seeds and oils. J Am Oil Chem Soc. 1995;72(3):309-315.

14. Putnam DH, Budin JT, Field LA, et al. Camelina:a promising low-input oilseed. In: Janick J, et al. editors. New crops. New York: Wiley; 1993. p. 314-322.

15. McVay KA, Lamb PF. Camelina production in Montana. Montana State Univ Ext Publ, 200701AG, Revised 3/08, Bozeman, Montana, USA: Montana State Univ; 2008.

16. Hess BW, Chen C, Foulke T, et al. Evaluation of Camelina sativa as 
an alternative seed crop and feedstock for biofuel and developing replacement heifers. Project number SW07-049, Sustainable Agriculture Research \& Education, USA: University of Maryland; 2011.

17. Sintim HY, Jeliazkov VD, Obour AK, et al. Camelina as a replacement for fallow in wheat-fallow rotation. ASA-CSSA-SSSA International Annual Meeting, Poster No:323, Long Beach, California, USA; 2014.

18. Johnston AM, Tanaka DL, Miller PR, et al. Oilseed crops for semiarid cropping systems in the Northern Great Plains. Agron J. 2001;94(2):231240.

19. Norwood CA. Dryland winter wheat as affected by previous crops. Agron J. 2000;92(1):121-127.

20. Nielsen DC. Comparison of three alternative oilseed crops for the central Great Plains. J Prod Agric. 1998;11(3):336-341.

21. Jaafar MN, Stone LR, Gordrum DE. Rooting depth and dry matter development of sunflower. Agron J. 1993;85(2):281-286.

22. Nielsen DC. Water requirements and potential impacts on following crops. In: Meyer R, et al. editors. High Plains sunflower production handbook. MF-2384. Agric Exp Stn, Manhattan, New York, USA: Kansas State Univ; 1999.

23. Downey RK, Rimmer SR. Agronomic improvement in oilseed Brassicas. Adv Agron. 1993;50:1-66.

24. Chen C, Jackson G, Karn es N, et al. Determining the feasibility of early seeding canola in the northern Great Plains. Agron J. 2005;97(4):12521262 .

25. Pavlista AD, Santraa DK, Isbell TA, et al. Adaptability of irrigated spring canola oil production to the US High Plains. Ind Crop Prod. 2011;33(1):165-169.

26. United States Department of Agriculture (USDA). Adoption of genetically engineered crops in the U.S. United States Department of Agriculture, USA; 2015.

27. Pavlista AD, Baltensperger DD, Isbell TA, et al. Comparative growth of spring-planted canola, brown mustard and camelina. Ind Crop Prod. 2012;36(1):9-13

28. Dosdall LM, Stevenson FC. Managing flea beetle (Phyllotreta spp.) (Coleoptera: Chrysomelidae) in Canada with seeding date, plant density and seed treatment. Agron J. 2005;97(6):1570-1578.

29. Pavlista AD, Isbell TA, Baltensperger DD, et al. Planting date and development of spring-seeded irrigated canola, brown mustard and camelina. Ind Crop Prod. 2011;33(2):451-456.

30. United States Department of Agriculture-Economic Research Service (USDA-ERS). Canola- soybeans \& oil crops. USA: United States Department of Agriculture- Economic Research Service; 2012.

31. Putnam ML, Serdani M, Ehrensing D, et al. Camelina infected by downy mildew (Hyaloperonospora camelinae) in the western United States: A first report. Plant Health Progress. 2009; doi:10.1094/PHP-2009-091001-BR.

32. Harveson RM, Santra DK, Putnam ML, et al. A new report for downy mildew [(Hyaloperonospora camelinae Gaum.) Goker, Voglmayr Riethm., M. Weiss \& Oberw. 2003] of camelina [Camelina sativa (L.) Crantz] in the High Plains of the United States. Plant Health Progress. 2011;doi:10.1094/PHP-2011-1014-01-BR.

33. Ehrensing DT, Guy SO. Camelina. Oregon State Univ, Ext Ser Publ, EM8953-E, Corvallis, Oregon, USA: Oregon State University; 2008.

34. Robinson RG. Camelina: a useful research crop and a potential oilseed crop. Bulletin: University of Minnesota Agricultural Experiment Station; 1987. $579 \mathrm{p}$.
35. Hulbert S, Guy S, Pan W, et al. Camelina production in the dryland Pacific Northwest. Washington State University Extension Serv, Publ. FS073E. Pullman, Washington, USA: Washington State University; 2012.

36. Gesch RW, Cermak CS. Sowing date and tillage effects on fall-seeded camelina in the Northern Corn Belt. Agron J. 2011;103(4):980-987.

37. Gesch RW, Archer DW. Camelina: A potential winter annual crop for the northern Corn Belt. (Abstract) (CD-ROM). ASA-CSSASSSA Annual Meet. Pittsburgh, PA. 1-5 Nov. 2009. ASA, Madison, Wisconsin, USA: CSSA and SSSA; 2009.

38. Vollmann J, Moritz T, Kargl C, et al. Agronomic evaluation of camelina genotypes selected for seed quality characteristics. Industrial Crops and Products. 2007;26(3):270-277.

39. Allen BL, Vigil MF, Jabro JD. Camelina growing degree hour and base temperature requirements. Agron J. 2014;106(3):940-944.

40. Adamsen FJ, Coffelt TA. Planting date effects on flowering, seed yield and oil content of rape and crambe cultivars. Industrial Crops and Products. 2005;21(3):293-307.

41. Berti M, Wilckens R, Fischer S, et al. Seeding date influence on camelina seed yield, yield components and oil content in Chile. Industrial Crops and Products. 2011;34(2):1358-1365.

42. McVay KA, Khan QA. Camelina yield response to different plant populations under dryland conditions. Agron J. 2011;103(4):1265-1269.

43. Schulte LR, Ballard $\mathrm{T}$, Samarakoon $\mathrm{T}$, et al. Increased growing temperature reduces content of polyunsaturated fatty acids in four oilseed crops. Industrial Crops and Products. 2013;51:212-219.

44. Enjalbert N, Johnson J. Guide for producing dryland camelina in eastern Colorado. Crop production fact sheet No. 0709. Fort Collins, Colorado, USA: Colorado State University; 2011.

45. Jha P, Stougaard RN. Camelina (Camelina sativa) tolerance to selected preemergence herbicides. Weed Science Society of America. 2013;27(4):712-717.

46. Jiang Y, Caldwell CD, Falk KC, et al. Camelina yield and quality response to combined nitrogen and sulfur. Agron J. 2013;105(6):1847-1852.

47. Urbaniak SD, Caldwell CD, Zheljazkov VD, et al. The effect of cultivar and applied nitrogen on the performance of Camelina sativa L. in the Maritime Provinces of Canada. Can J Plant Sci. 2008;88:111-119.

48. Obour AK, Krall JM, Nachtman JJ. Influence of nitrogen and phosphorus fertilization on dryland Camelina sativaseed yield and oil content. Agricultural Experiment Station 2012 Field Days Bulletin, Laramie, Wyoming, USA: University of Wyoming; 2012.

49. Johnson J, Enjalbert N, Schneekloth J, et al. Development of oilseed crops for biodiesel production under Colorado limited irrigation conditions. Final report no. 211, Colorado Water Institute; 2009.

50. Lenssen AW, Iversen WM, Sainju UM, et al. Yield, pests and water use of durum and selected crucifer oilseeds in two-year rotations. Agron J. 2012;104(5):1295-1304.

51. Moser BR. Camelina (Camelina sativa L.) oil as a biofuels feedstock:Golden opportunity or false hope? Lipid Technology. 2010;22(12):270-273

52. Zubr J, Matthaus B. Effects of growth conditions on fatty acids and tocopherols in Camelina sativa oil. Industrial Crops and Products. 2002;15(2):155-162.

53. Davis PB, Menalled FD, Peterson RDD, et al. Refinement of weed risk assessments for biofuels using Camelina sativa as a model species. $J$ Applied Ecol. 2011;48(4):989-997. 
54. Frohlich A, Rice B. Evaluation of Camelina sativa oil as a feed stock for biodiesel production. Industrial Crops and Products. 2005;21(1):25-31.

55. Soriano NU, Narani A. Evaluation of biodiesel derived from Camelina sativa oil. J the American Oil Chemists 'Society. 2002;89(5):917-923.

56. Shonnard DR, Williams L, Kalnes TN. Camelina-derived jet fuel and diesel:Sustainable advanced biofuels. Environmental Progress \& Sustainable Energy. 2010;29(3):382-392.

57. Korsrud GO, Keith MO, Bell JM. A comparison of the nutritional value of crambe and camelina seed meals with egg and casein. Can J Anim Sci. 1978;58:493-499.

58. Meadus WJ, Duff P, McDonald T, et al. Pigs fed camelina meal increase hepatic gene expression of cytochrome $8 \mathrm{~b} 1$, aldehyde dehydrogenase and thiosulfate transferase. J Anim Sci Biotechnol. 2014;5(1):1.

59. Salminen H, Estevez M, XKivikari R, et al. Inhibition of protein and lipid oxidation by rapeseed, camelina and soy meal in cooked pork meat patties. European Food Research and Technology. 2006;223(4):461-468.

60. Strabel MS, Cieslak A, Zmora P, et al. Camelina sativa cake improved unsaturated fatty acids in ewe's milk. J Sci Food Agric. 2011;91(11):20312037.

61. Colombini S, Broderick GA, Galasso I, et al. Evaluation of Camelina sativa (L.) Crantz meal as an alternative protein source in ruminant rations. $J$ the Science of Food and Agriculture. 2014;94(4):736-743.

62. Russo R, Reggiani R. Anti nutritive compounds in twelve Camelina sativagenotypes. American J Plant Sci. 2012;3(10):1408.

63. Morris E. Erucic acid again. Food Cosmet Toxicol. 1980;18(2):197-199.

64. Moriel P, Nayigihugu V, Cappellozza BI, et al. Camelina meal and crude glycerin as feed supplements for developing replacement beef heifers. $J$ Anim Sci. 2011;89(12):4314-4324.
65. Kasetaite S, Ostrauskaite J, X Grazuleviciene V, et al. Camelina oil- and linseed oil-based polymers with bisphosphonate cross links. J Applied Polymer Science. 2014;131(17):8536-8543.

66. Zaleckas E, Makareviciene V, Sendzikiene E. Possibilities of using Camelina sativa oil for producing biodiesel fuel. Transport. 2012;27(1):60-66.

67. Kim N, Li Y, Sun XS. Epoxidation of Camelina sativa oil and peel adhesion properties. Industrial Crops and Products. 2015;64:1-8.

68. Hu P, Wang AS, Engledow AS, et al. Inhibition of the germination and growth of Phymatotrichopsis omnivora (cotton root rot) by oilseed meals and isothiocyanates. Applied Soil Ecology. 2011;49:68-75.

69. United States Department of Agriculture-National Agricultural Statistics Service (USDA-NASS). Camelina acreage, yield and production, Montana, USA. United States Department of Agriculture- National Agricultural Statistics Service; 2013.

70. United States Department of Agriculture (USDA), Federal Crop Insurance Corporation (FCIC). Camelina Loss Adjustment Standards Handbook. USA: United States Department of Agriculture, Federal Crop Insurance Corporation; 2013.

71. Foulke T, Geiger ME, Hess BW. An analysis of on-farm feed and fuel from dryland camelina. J ASFMRA. 2012;75:43-56.

72. Keske CMH, Hoag DL, et al. Is it economically feasible for farmers to grow their own fuel? A study of Camelina sativa produced in the western United States as an on-farm biofuel. Biomass and Bioenergy. 2013;54:89-99.

73. Reddy N, Jin E, Chen L, et al. Extraction, characterization of components and potential thermoplastic applications of camelina meal grafted with vinyl monomers. J Agric Food Chem . 2012;60(19):4872-4879. 